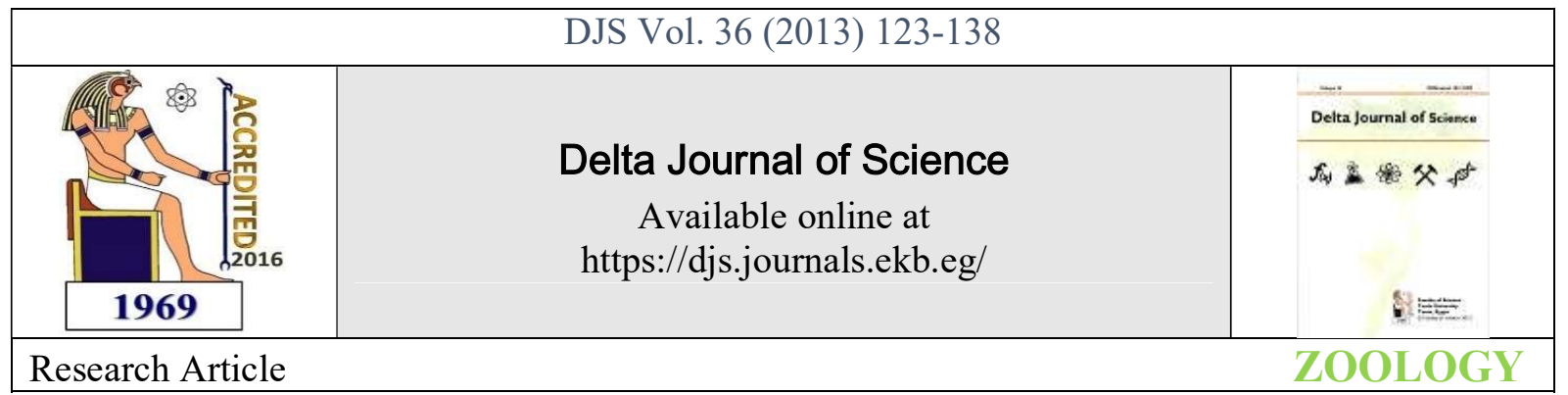

\title{
Immune -Toxicity of Synthetic Pyrethroids: Modulation of Cypermethrin and Permethrin
} Toxicity by Tamoxifen.

\author{
I. A. El Elaimy*, M. F.F. Bayomy*, T. A. Salem**, H. M. Ibrahim* \\ * Faculty of Science, Minufiya University, ** Genetic Engineering and Biotechnology Institute, Minufiya \\ University.
}

\begin{abstract}
Cypermethrin and permethrin are widely used in the agriculture in many countries. Continuous low level exposure of human to such chemicals may increase the susceptibility to various diseases due to the suppression of immune system. Therefore, the aim of the present study is to evaluate the toxicity of these pesticides at immunological, hematological and biochemical levels using tamoxifen as a modulatory agent against the toxicity of pyrethroids. The animal groups were intoxicated for 30 or 60 days with either cypermethrin or permethrin. The single effects of either pyrethroids or tamoxifen were studied. The double effects of both of tamoxifenpyrethroids were also investigated. It was found that pyrethroids alone decreased IgG level, while tamoxifen and tamoxifen plus pyrethroids increased its concentration. Pyrethroids, tamoxifen and tamoxifen in combination with pyrethroids had an inhibitory effect on lymphocyte stimulation index measured in vitro, phagocytic function of neutrophil and catalase activity. These treatment, however, increased relative ear thickness and contact hypersensitivity. In conclusion, these results raise some concerns about the possibility that tamoxifen may potentiate or attenuate the effects caused by pyrethroids.
\end{abstract}

Keywords: cypermethrin, permethrin, tamoxifen, lymphocyte, phagocytosis, IgG.

\section{INTRODUCTION}

Synthetic pyrethroids are an important family of pesticides. They are modified derivatives of pyrethrins, which are natural substances obtained from the flowers of Pyrrethrum cinerariaefolium and Pyrethrum carneum (Luty et al., 2000). Cypermethrin (cyp) and permethrin (per) are the most commonly used pyrethroids in agriculture and in domestic purpose. These chemicals are esters of carboxylic acid with three chirial centers located at carbons 1 and 3 of the cyclopropane ring and at the $\alpha$-carbon of the alcohol moiety. Cypermethrin has a cyano group, which contributed to mammalian toxicity (Surralles et al., 1995). Although the wide utilization of cypermethrin and permethrin as agricultural insecticides, their immunotoxic mechanisms are still unclear (Desi et al., 1985; Desi et al., 1986; Hoellinger et al., 1987; Madsen et al., 1996).

It was reported that these pyrethroids decrease the division rates of $\mathrm{T}$ - and B-lymphocytes in laboratory cultures, suggesting a functional impairment of these cells (Stelzer and Gordon, 1984; Blaylock et al., 1995). Permethrin also inhibited the mitogenic response of murine lymphocytes to phytohaemagglutinine (PHA), and decreased the production of interferon- $\gamma$ (IFN- $\gamma$ ) and interleukin-4 (IL-4) (Diel et al., 1998). Additional effects were identified from exposure of these lymphocytes to pesticides. For example, the elimination rates of foreign bodies were decreased when T-lymphocytes were exposed to permethrin (Blaylock et al., 1995). Likewise, the cytolytic activity of natural killer cells (NK) was also decreased upon exposure to permethrin (Blaylock et al., 1995). Santoni et al., (1999) suggested that the changes in mitogen-induced proliferative responses in the peripheral

blood and spleen of prenatally cypermethrin-exposed rats may be attributable to pesticide-induced catecholamine release, which causes an increase output of CD3+, CD4+ and CD8+ Tcells from spleen and peripheral blood and a consequent lymphocytosis.

Cypermethrin and deltamethrin exposure has been reported to lead to a reduced the ability of lymphocyte to bind antigens which was attributed to a decreased amount of antibody production (Desi et al., 1986; Lukowicz-Ratajczak and Krechniak, 1992a). The authors described dose-dependent reductions in humoral response in rabbits treated with $1 / 40$, $1 / 20$ or $1 / 10$ of the LD50 of cypermethrin. Furthermore, plaque-forming cells were also reduced in number, which is another indication of a diminished humoral response 
(Tamang et al., 1986). Pyrethroids may also affect the mechanisms of nonspecific humoral immunity. Thus application of $\alpha$-cypermethrin, having stimulatory effect on the synthesis of tumor necrosis factor- $\alpha(\mathrm{TNF}-\alpha)$ was observed in Swiss albino mice 28 days after treatment. The synthesis of IL-2 was inhibited or stimulated according to the dose of the pyrethroid and the gender of the animals used (Luty and Maj, 1998a).

Santoni et al. (1997) reported that rats prenatally exposed to cypermethrin during days 7 to 16 had a reduced thymus weight and decreased numbers of T-lymphocytes in this gland associated with an increased lymphocyte count in the peripheral blood, which may reflect an accelerated release of lymphocytes from the thymus.

Depending on the dose level, pyrethroids may exert a toxic, suppressive or stimulatory effect on the immunological system (Desi et al., 1985; Desi et al., 1986; Hoellinger et al., 1987; Lukowicz-Ratajczak and Krechniak, 1991; LukowiczRatajczak et al., 1992b; Madsen et al., 1996). The defensive capability of neutrophils changes as a result of the dermal absorption of $\alpha$-cypermathrin. This compound when administered in a dose 1/10 LD50 caused induction of phagocytic activity, however, higher dose 1/2 LD50 suppressed phagocytic activity (Luty et al., 1998c).

Tamoxifen has been used as a chemotherapeutic agent for oestrogen receptor positive neoplasias for the past two decades and has significantly increased patient survival. Furthermore, it has been shown to be efficacious in some oestrogen receptor negative tumours and as a prophylactic in those with family histories of breast cancer (MacGregor and Jordan, 1998). The mechanism of action of tamoxifen was originally thought to be based solely on its ability to competitively bind to oestrogen receptors. However, recent research has shown that its actions are more complicated. Tamoxifen has both agonist and antagonist actions at oestrogen receptors. For example, while tamoxifen competes for binding with oestrogen receptors in breast tissue, it has oestrogenic actions on bone and lipid metabolism (Watanabe et al., 1997). Many of the benefits of tamoxifen chemotherapy come from this dual activity since it can be used as an anti-oestrogen in breast tissue but at the same time preserve bone density and be cardioprotective due to its oestrogenic action. Whether oestrogenic or anti-oestrogenic actions are seen relate not only to tissue/cell type but also to whether binding occurs to either A1 or A2 transcription activating factors and to the ratio of oestrogen receptor subtypes $\alpha$ and $\beta$ present in the tissue (Watanabe et al., 1997; Kuiper et al., 1998). Further research has shown that tamoxifen, along with its metabolite, 4-hydroxy-tamoxifen, has non-genomic actions that may contribute to its anti-tumor activity (MacGregor and Jordan, 1998; Kostrzewska et al., 1997; Cantabrana and Hidalgo, 1992). Csaba and Inczefi-Gonda (2000) proved that single injection of tamoxifen to newborn rats causes a faulty imprinting in thymic receptors, increasing affinity and density of males, and decreasing females' glucocorticoid receptors as well as decreasing the density of uterine estradiol receptors.

When the adult intact and castrated male rats were treated with tamoxifen for long term, the results showed the following: (1) Age-related involution of the male thymus from the juvenile period through puberty to post puberty depends on the rising testosterone levels and represents mainly a decrease of thymic lymphoid-cell elements. (2) Tamoxifen administration reverses thymic involution in intact adult male rats and this effect is related to a dose-dependent, tamoxifen-induced castration and decrease of testosterone levels. (3) The changes of circulating testosterone levels, either resulting from maturity, or induced by tamoxifen or by castration, have a minimal effect on splenic growth and weight. (4) In contrast to intact animals, administration of tamoxifen at pharmacological doses to adult castrated rat's results in thymic regression. These findings revealed that tamoxifen is able to reverse aging changes in the thymus by suppressing testosterone production, whereas it exerts thymolytic effects in the absence of androgens (Sfikakis et al., 1998)

Pasqualinni et al., (1984) reported that tamoxifen provokes a selective decrease the larger and actively proliferating lymphoid cells of the cortical zone. Moreover, Leitner et al. (1996) reported that tamoxifen strongly inhibited humoral immune response to E. coli and sheep red blood cells (SRBC) antigen in avian. In addition, tamoxifen has stimulatory effect on overall cytokine production in B-cell line, whereas on a Tcell line, it stimulated IL- $1 \beta$, IL- 6 and IFN- $\gamma$ production (Jarvinen et al., 1996).

Pretreatment of T-cell enriched-preparations with "therapeutic" concentrations of tamoxifen augmented their capacity to promote IgG but not IgM secretion of untreated autologous B-lymphocytes (Baral et al., 1986). Fishelson et al., (1992) proved that tamoxifen blocked the action of leukoregulin (LR) which is a lymphokine secreted by human natural killer cells. In patients undergoing adjuvant therapy with tamoxifen, an increase of reactivity in the leukocyte migration inhibition test against tumor tissue and increase in the percentage of natural killer cells were observed (Mallmann et al., 1990).

In breast cancer patients, the lymproliferative response to PHA was reduced sharply when they were treated with tamoxifen (Scambia et al., 1988). Tamoxifen treatment resulted in diminished expression of C3-receptors on the cells as detected (Baral et al., 1985). Tamoxifen also inhibits the phagocytosis of rod outer segments by retinal pigment epithelium in both human retinal pigment epithelial cell line D407 and pig retinal pigment epithelial cells (Mannerstrom et al., 2001). The results show a reduction in the activity of the retinal pigment that removes the outer segment of photoreceptor cells by phagocytosis after tamoxifen exposure (Toimela et al., 1995). Current evidence clearly indicated that free radicals play a prominent role in the incidence and development of breast cancer. Tamoxifen-treated patients showed remarkably increased levels of enzymic and nonenzymic antioxidants (Thangaraju et al., 1994). The activity of glutathione S-transferase and hexose monophosphate shunt (HMS) in rat liver were permanently induced by the high dose of tamoxifen (Ahotupa et al., 1994).

The aim of the present study is to investigate the modulatory action of tamoxifen as antiestrogenic compound on the subchronic immunotoxic effect of pyretheroids in male Wistar rats.

\section{Materials and Methods}

\subsection{Insecticides used:}

Two pyrethroids exhibiting two different structures purchased from Help Pesticides and Chemicals Company (Free Zone, New Damietta, Egypt) were used:

A - Cypermethrin: $\alpha$-cyano-3-phenoxybenzyl(1RS)cis,trans-3-(2,2-diclorovinyl)-2,2-dimethyl-cyclopropane carboxylate of $95 \%$ purity.

B - Permethrin: 3-phenoxybenzyl-3-(2,2-dichlorovinyl)-2,2dimethyl-cyclopropane carboxylic acid of $92 \%$ purity. 
Both insecticides are used in a large scale in Egypt. They were dissolved in pharmaceutical-grade sesame oil.

\section{C- Anticancer used (Tamoxifen):}

Tamoxifen: ([Z]-1-[P-Dimethyl amino ethoxyphenyl]-1,2diphenyl-1-butene) was purchased from Sigma, USA.

\subsection{Experimental animals:}

Four to six week-old outbred albino male Wister rats with average weight of $100-150 \mathrm{~g}$ were purchased from the Egyptian Organization for Biological and Vaccine Production, Cairo, Egypt., and kept under conventional conditions in the animal house, Zoology Department, Faculty of Science, Minufiya University. Standard rodent food and water were available at all times. The animals were acclimatized to laboratory condition for about one week before the experiments.

\subsection{Experimental design:}

The acute oral LD50 of both compounds was determined by the method of Litchfield-Wilcoxon (1949) on 8-week old male Wistar rats using eight doses and six animals per dose. In the present study, equitoxic doses of 1/60 LD50 (Cypermethrin: $1.0 \mathrm{mg} / \mathrm{kg}$ and permethrin: $12.9 \mathrm{mg} / \mathrm{kg}$ ) were dissolved in pharmaceutical-grade sesame oil. Sixty rats were divided into six groups of 10 rats for each group:

Group (1): Composed of two subgroups (five rats each) received sesame oil orally at similar volumes as the treated groups and was considered as controls.

Group (2 and 3): Composed of four subgroups (five rats each) received orally equitoxic doses of $1 / 60 \mathrm{LD}_{50}$

Group (4): Composed of two subgroups (five rats each) received orally tamoxifen $(1.8 \mathrm{mg} / \mathrm{kg})$ that equivalent to daily human therapeutic dose after conversion to rats (Paget and Barnes, 1964).

Group (5 and 6): Composed of four subgroups (five rats each) received orally modulated by Tamoxifen $(1.8 \mathrm{mg} / \mathrm{kg})$.

\subsection{Blood and tissue samples:}

Blood was collected from the hepatic portal vein of the rats. Each blood sample was divided into two tubes, one of them was mixed with heparin and the other was permitted to clot. The tubes were centrifuged in a cooling centrifuge at 3000 $\mathrm{rpm}$ for $15 \mathrm{~min}$ to separate blood serum. The separated serum was sampled into clean tubes and kept in a deep-freezer at $50^{\circ} \mathrm{C}$

Liver, thymus, spleen and testes were excised and blotted using filter paper placed in plastic containers and kept in a deep-freezer at $-50{ }^{\circ} \mathrm{C}$ till further analyses were performed.

\subsection{Toxicological and haematological parameters}

The organ relative weight was done for each animal by dividing the organ weight by the animal weight.

For hematological studies, total leukocytic count (WBC), absolute differential white blood cell count; was done manually according to method described by (Dacie and Lewis, 1991)

\subsection{Immunological parameters}

Lymphocytes were isolated from the heparinized blood sample according to the method of Boyum et al. (1968). Lymphoproliferative response to mitogen was carried out by culturing the lymphocytes with phytohemagglutinine (PHA) under complete sterile conditions for three days at $37^{\circ} \mathrm{C}$ at $5 \%$
$\mathrm{CO}_{2}$ incubator. The stimulation index was estimated by incorporating ${ }^{3} \mathrm{H}$-thymidine in the culture medium at the third days and measured using $\beta$ - scintillation counter (Colley et al., 1979).

The innate immunity was evaluated by investigating the phagocytic function of the neutrophils. Briefly, neutrophils were isolated from the heparinized blood sample according to the method of Markert et al. (1984) and incubated with boiled yeast cells for $30 \mathrm{~min}$ at $37^{\circ} \mathrm{C}$. Then, the reaction was stopped by putting the tubes in ice cold water. The phagocytic

index was estimated by checking the phagcytic cells under ordinary light microscope according to the method of Timothy et al. (1997)

The humoral immunity was evaluated by measuring the level of IgG in the serum of animals using radial immunodiffusion plates (RID) according to the method of Mancini et al. (1965). The contact hypersensitivity response (relative ear thickness) assay was performed according to Gad et al., (1986).

\subsection{Biochemical assays}

Protein content was determined in liver homogenate according to the method of Lowry et al. (1951). Catalase activity as antioxidant enzyme was determined in the liver homogenate according to the method of Aebi, ((1974)

\subsection{Data processing}

Data were collected and analyzed by using SPSS software ${ }^{\circledR}$. The statistical analyses were carried out by Independent Student-t test and one-way ANOVA, setting the probability level to $P<0.05$, post hoc analysis of group differences was performed by LSD test. The treated groups were compared to each other and with untreated control group.

\section{RESULTS}

Table (1) demonstrates the effect of pyrethroids on the relative organ weights. No significant change was observed on the relative spleen weights in rats as a result of treatment of cypermethrin. Permethrin showed a significant increase in the relative spleen weight $(\mathrm{P}<0.05)$ when compared to that of the control group after 30 days of intoxication. Also, no significant effect was recorded for the relative spleen weight upon the treatment with tamoxifen after the same period of treatment. The modulatory effect of tamoxifen was demonstrated when it was combined with cypermethrin that displayed significant elevation in the relative spleen weight $(p<0.01)$ when compared to that of cypermethrin treated group after 30 days. After 60 days no significant effect was observed upon the treatment with pyrethroids, tamoxifen or co-exposure of pyrethroids with tamoxifen.

As shown in Table (1), the relative liver weight was significantly increased $(p<0.001)$ in rats treated with either permethrin or cypermethrin when compared to that of the control group after 30 days. Also, tamoxifen had the same effect after the same period. Moreover, in intoxicated rats treated with co-exposure of pyrethroids with tamoxifen, the relative liver weight was significantly increased $(p<0.05)$ when compared to those of permethrin or cypermethrin intoxicated group.

After 60 days, rats treated with either pyrethroid displayed a significant decrease in relative liver weight when compared to that of the control. On the other hand, treatment with tamoxifen alone, indeed, revealed a significant increase $(p<0.05)$ in the relative liver weight. Similar effect was observed in relative liver weight in rats treated with 
tamoxifen-pyrethroid intoxicated rats when compared to those treated groups with pyrethroids.

As shown in Table (1) A significant decrease $(p<0.05)$ in the relative testes weight in male Wister rats treated with permethrin was observed, while no significant change was observed upon treatment of cypermethrin or tamoxifen for 30 days when compared with their respective control group. In tamoxifen-permethrin treated rats, the relative testes weight was significantly reduced $(\mathrm{p}<0.05)$ when compared to that of the permethrin group. After 60 days, the relative testes weight was significantly reduced $(p<0.05)$ in pyrethroids treated groups when compared to those of control groups. Moreover, the relative testes weight was significantly decreased $(p<0.001)$ in rats treated with tamoxifen. Rats treated with both permethrin and tamoxifen or cypermethrin and tamoxifen displayed a significant drop in relative testes weight as compared to either permethrin or cypermethrin only.

As shown in Table (1) a significant decrease $(p<0.05)$ in the relative thymus weight in rats treated with either permethrin or cypermethrin was observed when compared to that of the control group after 30 days, while rats treated with tamoxifen displayed a significant increase $(p<0.05)$ after the same experimental period. the relative thymus weight was significantly increased $(\mathrm{p}<0.05)$ in male Wister rats upon treatment with tamoxifen-pyrethroids when compared to each pyrethroid alone after 30 days.

After 60 days, rats treated with permethrin displayed a significant decrease in the relative thymus weight, as compared to its control group. No significant effect in rats upon treatment with cypermethrin after the same period. Tamoxifen induce a significant increase $(p<0.05)$ in rats. However, tamoxifen was able to modulate the pyrethroids effect thus, increases in the relative thymus weight was observed.

Table (2) shows the effect of the chronic doses of type I and II pyretheroids and tamoxifen- pyrethroids on the total leukocytic count. The results indicated that the subchronic doses of permethrin, cypermethrin or tamoxifen after 30 days caused significant decreases in total leukocytic count $(P<0.05)$ in male Wistar rats compared to those of the control group. Rats treated with both permethrin and tamoxifen or cypermethrin and tamoxifen displayed significant increases in the total leukocytic counts, as compared to permethrin or cypermethrin alone after 30 days. No significant change was observed in rats treated with permethrin, cypermethrin or tamoxifen after 60 days, only rats that exposed to tamoxifenpermethrin showed a significant increase in total leukocyte counts, as compared to permethrin alone after 60 days.

Table (3) demonstrates the effect of chronic treatment of pyrethroids or co-exposure of animals to both pyrethroids and tamoxifen on absolute differential count of leukocytes. Significant decreases $(P<0.05)$ were observed in the absolute lymphocyte counts in rats treated with cypermethrin, while no significant change was demonstrated upon treatment of permethrin when compared to that of its control group after 30 days. Moreover, a significant decrease was demonstrated in rats upon treatment with tamoxifen after the same period. Rats treated with tamoxifen- permethrin only displayed a significant increase $(p<0.05)$, as compared to that of the permethrin group after 30 days.

As shown in Table (3) a significant decrease $(\mathrm{p}<0.05)$ of the absolute monocyte and granulocyte counts were observed in rats treated with either permethrin or cypermethrin when compared to their respective control groups after 30 days. Also, similar effect was observed upon treatment with tamoxifen. Rats treated with both tamoxifen and permethrin or cypermethrin displayed significant increases $(p<0.05)$ in both the absolute monocyte and granulocyte counts when compared to those of the permethrin or cypermethrin groups after 30 days.

After 60 days no significant change in the absolute lymphocyte and granulocyte counts was observed upon treatment with pyrethroids when compared to those of control groups. Only a significant decrease in the absolute monocyte count was observed in rats treated with either cypermethrin or tamoxifen when compared to that of the control group. Rats treated with tamoxifen -pyrethroids (permethrin or cypermethrin) displayed no significant changes in the absolute monocyte, lymphocyte and granulocyte counts, as compared to either permethrin or cypermethrin.

The effects of chronic treatment of rats with pyrethroids and co-exposure of rats to both pyrethroids and tamoxifen on lymphocyte response to mitogen, expressed as stimulation index (SI) were shown in Table (4). Significant decreases $(P<0.001)$ were observed in rats treated with both permethrin and cypermethrin after 30 days and 60 days when compared to those of the control groups. Similar effects were noticed when rats were treated with tamoxifen after the same experimental periods and no modulatory effect was observed in rats treated with pyrethroids with tamoxifen after the periods of treatment.

Table (5) illustrates the effect of chronic doses of pyrethroids and co-exposure of pyrethroids with tamoxifen on the phagocytic function of neutrophils, expressed as phagocytic index. A significant decrease $(P<0.001)$ was observed in rats upon treatment with permethrin, cypermethrin and tamoxifen after 30 and 60 day when compared to those of the control groups. Rats treated with both permethrin and tamoxifen or cypermethrin and tamoxifen displayed a significant drop in phagocytic indices, as compared to permethrin or cypermethrin alone after 30 days. On the other hand, the phagocytic index was significantly increased in tamoxifen permethrin group when compared to that of permethrin treated group after 60 days.

The effect of chronic treatment of pyrethroids and co-exposure of pyrethroids with tamoxifen on the serum level of immunoglobulin G (IgG) was shown in Table (6). The results indicated that type I and II pyrethroids caused a significant decrease $(P<0.05)$ in the level of IgG when compared to the control group. On the other hand, treatment with tamoxifen for 30 and 60 days significantly increased $(P<0.05)$ the IgG level when compared to the control group. Also, the combined influence of pyrethroids and tamoxifen has led to significant increases $(P<0.001)$ in IgG levels after 30 and 60 days of treatment, as compared to their respective pyrethroid groups.

The effects of pyrethroids and tamoxifen on the liver catalase activity are shown in Table (7). The results demonstrated that type I and II pyrethroids significantly reduced $(P<0.01)$ the catalase activity when orally administrated to rats for 30 and 60 days, compared to control group. Also, catalase activity was significantly diminished $(P<0.01)$ upon treatment with tamoxifen for 30 and 60 days. The data also showed that tamoxifen exhibits no modulatory action on the pyrethroid intoxicated groups.

Tables (8A and B) illustrate the effects of topical application of permethrin and cypermethrin, on the contact hypersensitivity response measured as relative ear thickness (RET). The results demonstrate that topical application of subchronic dose of permethrin to rats for 0 day, 30 and 60 days caused significant increases in the RET, compared to the control group. The results also show that tamoxifen 
significantly increased $(P<0.05)$ the RET when applied alone to rats for 0 day and 30 days, compared to the control group. Tamoxifen- permethrin treatment increased the RET compared to that of permethrin alone after 30 days, while, no significant change was observed after 60 days.

As shown in table (8B), cypermethrin significantly increased $(P<0.05)$ the RET when topically applied to male Wistar rats for 0 day, 30 and 60 days, compared to the control group. Also, a significant increase $(P<0.05)$ was observed in RET in tamoxifen- cypermethrin treated group when compared to that of the control group. Tamoxifen- cypermethrin treatment seems to be significantly decreased $(P<0.05)$ when compared to that of the cypermethrin alone after 30 and 60 days.

Moreover, topical application of chronic treatment of pyrethroids (permethrin and cypermethrin) and also tamoxifen -pyrethroids treatment to male Wistar rats for 30 and 60 days caused a significant inhibition in the RET compared to these groups at 0 day.

\section{Discussion}

The present study investigated the immunotoxic effect of two synthetic pyrethroids commonly used in agricultural purposes, (cypermethrin and permethrin). and the ability of tamoxifen (anticancer agent) to modulate the immunotoxic effect of these pyrethroids.

The results of the present study demonstrated that after 30 days, rats treated with pyrethroids showed a significant increase in the relative liver weight. On the other hand, a significant decrease in the relative thymus weights. Only permethrin showed a significant increase in the relative spleen weights, conversely, a significant decrease in the relative testes weights. Tamoxifen alone and co-exposure of each pyrethroid with tamoxifen illustrates a significant increase in the relative liver and thymus weights when compared to their respective pyrethroid groups. In contrary, co-exposure of permethrin with tamoxifen demonstrates a significant decrease in the relative testes weight when compared to their respective permethrin group. After 60 days, rats treated with pyrethroids illustrate a significant decrease in the relative liver and testes weights. Moreover, permethrin alone show a significant decrease in the relative thymus weights when compared to that of the control group.

Tamoxifen alone and co-exposure of each pyrethroid with tamoxifen showed no a significant change in the relative spleen weight, a significant increase in the relative liver and thymus weights, while, a significant decrease in the relative testes weight when compared to their respective pyrethroid groups.

The results of the present study are coincident with those obtained by Siroki et al. (1994) who reported a reduction in the relative liver weight in male CFLP mice after treatment with supercypermethrin. Krechniak and Wrzesniowska (1991) demonstrated irregular changes in the relative liver weights of rats following 20-days oral administration with 80 $\mathrm{mg} / \mathrm{kg}$ cypermethrin. In other studies undertaken by Parker et al. (1984a, b); Hext et al. (1986); Ishmael and Litchfield (1988); Schoenig (1995) and IRIS (2001a, b) the authors indicated an increased liver weights, congestion, hepatocellular hypertrophy and other microscopic signs of changes in liver of experimental animals during intermediate and chronic oral administration of pyrethroids. Administration of permethrin at doses of 12.6, 50.3 and 125.7 $\mathrm{mg} / \mathrm{kg}$ caused an increase of relative liver weight in male Wister rats (Kadota et al., 1975; Killen and Rapp, 1976; Clapp et al., 1977; Hart et al., 1977; Metker et al., 1977 and Institoris et al., 1999a). In another investigation, Institoris et al., (1999b) reported an elevation in the relative liver weights in four weeks old male Wister rats following treatment with cypermethrin. Dési et al. (1986) revealed that treatment with cypermethrin at doses of $6.25,12.5$ and 25 $\mathrm{mg} / \mathrm{kg} /$ day for 6 and 12 weeks lead to non-significant changes in relative spleen. Our findings are consistent with the results of Madsen et al. (1996) who indicated that cypermethrin had no effect on relative spleen weight; and deltamethrin deceased relative thymus weights after 28 days of treatment in male F344 rats. The results of our study are also in agreement with the results of Forsberg (2000) who found that eight-week-old NMRI mice treated neonatally with tamoxifen, which displayed an enlargement in the thymus. Moreover, it was reported that treatment with tamoxifen leads to a significant reduction in spleen weight (Kosaka and Yamashita, 1992). In addition, Gill-Sharma et al. (2001) reported that the relative testes weight was significantly reduced in male Wistar rats after oral administration of tamoxifen at a dose of 0.4 $\mathrm{mg} / \mathrm{kg} /$ day for 120 days.

A comparative study was carried out on different strains of experimental animals (rats) to investigate the effect of tamoxifen on relative liver weight and cell proliferation for 26 weeks of treatment. In Wistar and Lewis but not F344 rats, there was a marked increase in hepatocellular proliferation during the first 4 weeks of treatment. The onset of the proliferative response was delayed for thirteenth week in the F344 strain (Stanley et al., 2001). Tamoxifen users displayed a significant increase in the level of liver fats (Nguyen et al., 2001). Treatment with $\mathrm{TAM}^{+}$phenobarbital $(20 \mathrm{mg} / \mathrm{kg}$ per day) for 6 weeks of, female lambda/lacI transgenic rats resulted in time-dependent increases in liver weight compared with the corresponding controls (Styles et al., 2001).

The results of the present study demonstrated a significant decrease in the total leukocyte count, absolute lymphocyte, monocyte and granulocyte counts were observed in rats treated with pyrethroids or tamoxifen when compared to that of the control group after 30 days. While no significant change was demonstrated in the absolute lymphocytes count upon the treatment of permethrin alone. The combined influence of pyrethroids and tamoxifen display an increase in the total leukocyte count, absolute monocyte and granulocyte count in male Wister rats when compared to their respective pyrethroid groups. Co-exposure of permethrin with tamoxifen only displayed an increase in absolute lymphocyte count. After 60 days no significant change in the absolute lymphocyte and granulocyte count was recorded. Only a significant decrease in the absolute monocyte count was observed in rats treated with either tamoxifen or cypermethrin. Co-exposure to pyrethroids plus tamoxifen showed a minimal increase in the total leukocyte count. These findings are consistent with the results of Varshineya et al. (1992) who reported that cypermethrin reflected a depression of cellular response accompanied by leucopenia. Also, cypermethrin decreased white blood cell counts recorded in studies undertaken by Institoris et al. (1999a) and Krishnappa et al. (1999). Komi and Lassile, (2000) showed that tamoxifen inhibited the differentiation of white blood cells, especially for lymphocytes. Also, Sabbioni et al. (1999) reported that tamoxifen induced a decrease in lymphocytes and its subset counts. In addition, Grey et al. (1997) illustrated that $20 \mathrm{mg} /$ day of tamoxifen over two years resulted in a significant decline in the total leukocyte count.

The results of this work demonstrated that oral administration of 1/60 of LD50 of pyrethroids or tamoxifen to rats for 30 and 60 days resulted in a significant inhibition in lymphocyte proliferation to mitogen. Co-exposure of permethrin or cypermethrin with tamoxifen increased the inhibitory effect of pyrethroids on lymphocyte proliferation to mitogen.

Stelzer and Gordon, (1984) proved that permethrin and cypermethrin inhibited the $\mathrm{T}$ cells and $\mathrm{B}$ cells proliferation in 
vitro. Santoni et al. (1998) noticed a reduction in mitogeninduced $\mathrm{T}$-cell proliferation in prenatal exposure pregnant female Wister rats orally administrated $50 \mathrm{mg} / \mathrm{kg}$ of cypermethrin. Several lines of evidence indicate that type II pyrethroids are strong inducers of both adrenaline and noradrenaline release (Ray and Cremer, 1979; Cremer and Seville, 1982; Bradburry et al., 1983; Ray, 1991), and both adrenaline and noradrenaline in vitro inhibit Con-A induced proliferation of murine thymus cells (Cook-Mills et al., 1995). Moreover, Wu et al. (2000) indicated that tamoxifen inhibits the induction of T-cell by interleukin-2 (IL-2). In addition, tamoxifen, at concentration of 0.1 to1 $\mathrm{M}$ significantly inhibited the response of rat spleen cells to phytohemagglutinin (PHA), concanavalin-A (Con-A) and pokeweed mitogen (PWM) in a dose-dependent manner (Baral et al., 1994; Baral et al., 1989). Also, it was reported that treatment with tamoxifen leads to a general inhibition of lymphocyte proliferation to PHA in vitro (Baral et al., 2000) and in breast cancer patients (Scambia et al., 1988).

The phagocytic function of neutrophils in rats treated with pyrethroids or tamoxifen for 30 and 60 days. These results demonstrated significant reductions compared to those of the control group. Co-exposure of each pyrethroid and furthermore, tamoxifen potentiate this inhibitory effect on the phagocytic function of neutrophils.

In this respect the results agree with the others especially those recorded by Punareewattana et al. (2001), who reported that the ability of permethrin to inhibit the production of $\mathrm{H} 2 \mathrm{O} 2$ by splenic macrophages 2 days post-exposure. The same finding was proved by Gassner et al. (1997) who demonstrated that permethrin inhibits mitochonderial complex I, which may interfere with the electron transport chain and thus the respiratory metabolic burst of the phagocytic cells. Also, Luty et al. (2000) proved that the administration of $\alpha$ cypermethrin at doses of $1 / 2$ and $1 / 5$ LD50 to Swiss mice for 28 days resulted in a lower bactericidal activity of neutrophils as demonstrated using the nitroblue -tetrazolium test (NBT). As regard to tamoxifen, Lukac et al. (1994) indicated that tamoxifen exhibited an inhibitory effect on phagocytic function of macrophages in vitro. Tamoxifen also inhibited the phagocytosis of rod outer segments by retinal pigment epithelium in both human retinal pigment epithelial cell line D407 and pig retinal pigment epithelial cells (Mannerstrom et al., 2001). Baral et al. (1994) reported that tamoxifen inhibited phagocytosis and block $\mathrm{H} 2 \mathrm{O} 2$ production by human neutrophils.

Oral administration of chronic dose of pyrethroids to male Wistar rats leads to a significant decrease in the level of IgG when compared to those of the control group. On the other hand, IgG level was elevated upon treatment with tamoxifen. Moreover, tamoxifen when combined with each pyrethroid was able to modulate effect of pyrethroids.

Hadnagy et al. (2003) reported that pyrethroids cause a significant decrease in the $\mathrm{IgG}$ concentrations in volunteer persons. Also, Siroki et al. (1998) demonstrated that the treatment with supercypermethrin resulted in a reduction in the splenic Ig plaque-forming cells (Ig-PFC) number. A significant reduction in humoral immune response was observed at the $25 \mathrm{mg} / \mathrm{kg} /$ day of pyrethroids for 6 or 12 weeks (Dési et al. 1986). The present results are consistent with those which reported that tamoxifen has an inhibitory action on suppressor T-lymphocytes and in some situations this could lead to enhancement of immunoglobulin secretion by Blymphocytes (Baral et al., 1994). Paavonen et al. (1991) proved that tamoxifen can increase plaque-forming cells response of peripheral blood lymphocytes and subsequently causes an increase in the number of Ig-secreting cells in PWM stimulated cultures.

The influence of subchronic doses of type I and II pyrethroids on liver catalase activity in male Wistar rats treated orally for 30 and 60 days, demonstrated that both permethrin and cypermethrin have significantly reduced the catalase activity in the liver. Tamoxifen also caused a significant decrease in liver catalase activity when compared with control group. Meanwhile, tamoxifen exhibited no modulation effect on the catalase activity when administrated with pyrethroids.

Previous studies reported that an increase in the oxidative damage in rat erythrocytes was followed by a reduction in antioxidant enzymes (Bagnasco et al., 1991; Bainy et al., 1993; Oruc and Uner, 2000; Gabbianelli et al., 2002). This might be result from $\mathrm{O} 2$ production or a direct action of pesticides on the synthesis of the enzyme. Moreover, Punareewattana et al. (2001) reported that permethrin inhibited the production of $\mathrm{H} 2 \mathrm{O} 2$ in splenic macrophages. The presence of hydrogen peroxide could stimulate an increase of the catalase activity (Aebi, 1974). Accordingly, we can assume that the inhibition of $\mathrm{H} 2 \mathrm{O} 2$ may lead to the remarkable inhibition of catalase activity in rat liver homogenate. In addition, the gradual decrease in erythrocyte catalase activities over a period of time in rats treated with pyrethroid shows a decrease in reactive oxygen species generation due to metabolism and excretion of these pyrethroids (Kale et al., 1999).

The results of the present study are in agreement with the results of Caballero et al. (2001) who indicated that tamoxifen might cause alterations in liver cell homeostasis and thereby leads to liver damage and subsequently increases the reactive oxygen species (ROS). The diminished catalase activity in tamoxifen-treated animals might result of its sensibility to at least one of the ROS generated under oxidative stress. Inhibition of catalase could be the consequence of an irreversible autocatalytic process, in which the sustained increase of ROS would finally lead to cellular death (Pigeolet et al., 1990). In another study, raloxifene treatment had no statistically significant effect on catalase activity measured in the plasma of neurodegenerative diseased and cerebral ischemic patients (Oga et al., 2003). These results are consistent with the observation of Thangaraju et al. (1995) who reported that tamoxifen is potent suppressor of lipid peroxidation through the favorable effects on membrane lipid and protective enzyme system.

The topical application of subchronic doses of permethrin to male Wistar rats for 0 day, 30 and 60 days caused a significant increase in the contact hypersensitivity response measured as a relative ear thickness (RET) when compared to the control group. In addition, cypermethrin showed a remarkable increase in RET when applied for 0 day, 30 and 60 days, compared to the control group. Meanwhile, tamoxifen exhibited a stimulatory effect on the contact hypersensitivity response. No remarkable modulation was observed when tamoxifen was combined with pyrethroids.

Previous studies have revealed that pyrethroids induced the human basophils to release the histamine, which is the essential element for hypersensitivity reaction (Diel et al., 1999). The same finding was proved by El-Elaimy et al., (1990) who reported that cypermethrin stimulated the release of histamine into the blood of poisoned rats. Exposure to pesticides caused tissue damage that may lead to release of basic polypeptide or protein fractions that have direct action on cells producing histamine causing its exocytosis (Bayoumi et al., 1979; Hassan et al., 1985). In injured tissues, histamine released from damaged cell, increase capillary permeability. 
Thus it is probably responsible for some of the swelling in the area of inflammation (Ganong, 1989). Pollutants, like pyrethroids, have been proposed as causative agents of increasing allergic disease and hypersensitivity, although this is a controversial area (Pauluhn, 1996; Davies and Magnussen, 1997). This observation is consistent with the finding of Moya-Quiles et al. (1996) who proved that pyrethroids interfere with the packing order of cell membranes and hence may cause histamine release via a non-specific mechanism. The results also are confirmed with the observation that eight-week-old female and male NMRI mice treated, at neonatal period, with the synthetic tamoxifen exhibited delayed-type hypersensitivity (DTH) response (Forsberg, 2000).

Beside the differences in strains, sub-strains, doses, and treatment schedules, the contradictory results in the literature can probably be attributed to differences in purity and cis : trans ratio of cypermethrin or permethrin used.

In conclusion, tamoxifen may increase the risk of either effects or adverse immuno-toxicological effects caused by pyrethroids. This may be explained on the basis of its mechanism of action which was originally thought to be based solely on its ability to competitively bind to oestrogen receptors, however recent research has shown that its actions are more complex than expected (Watanabe et al., 1997).

Tamoxifen has both agonistic and antagonistic actions at oestrogen receptors. For example, while tamoxifen competes for binding with oestrogen receptors in breast tissue it has oestrogenic actions on bone and lipid metabolism (Watanabe et al., 1997).

Pyrethroid pesticides showed also estrogenic potential. Such estrogenic potentialities were ranked as Permethrin > cypermethrin $>$ deltamethrin (Chen et al., 2002). Sex hormones can strongly influence immune response (Clemens et al., 1979; Forsberg, 1984). Moreover, both estrogen and progesterone receptors have been identified recently in human lymphocytes (Cohen et al., 1983; Purdom , 1983; Forsberg, 1984).

In conclusion, it can be suggested that altered immune responses in male rats occurred after oral administration of subchronic doses of type I and II pyrethroids, including antibody production, which have high concordance (predictive values) for immunosuppression in rats. Beyond immunosuppression, data also, suggest possible increased incidence of allergic effects associated with chronic exposure to pyreth -roids. The presence of $\alpha$-cyano group in cypermethrin provokes its immunotoxic action compared to permethrin. For the same reason, permethrin being more permeable it easily filters through the membrane compared to cypermethrin influencing more intracellular enzymatic activity.

\section{References}

Aebi, H. (1974): Catalase. In: Methods of enzymatic analysis. Bergemeyer, H. V. (ed.), Public Academic Press, New York, 673-684.

Ahotupa, M., Hirsimaki, P., Parssinen, R., Mantyla, E. (1994): Alterations of drug metabolizing and antioxidant enzyme activities during tamoxifen-induced hepatocarcinogenesis in the rats. Carcinogenesis, 15(5):863-8.

Bagnasco, M., Camoirano, A., De Flora, S., Melodia, F., Arillo, A. (1991): Enhanced liver metabolism of mutagens and carcinogens in fish living in polluted seawater. Mutat. Res. 262, 129-137.
Bainy, A.C.D., Arisi, A.C.M., Azzalis, L.A., Simizu, K. Barios, S.B.M. (1993): Differential effects of short-term lindane administration on parameters related to oxidative stress in rat liver and erythrocytes. J. Biochem. Toxicol. $8,187-194$

Baral, E., Blomgren, H., Rotstein, S., Virving, L. (1985): Antiestrogen effects on human blood lymphocyte subpopulations in vitro. J Clin Lab Immunol , 17(1):33-5.

Baral, E., Blomgren, H., Wasserman, J., Rotstein, S., von Stedingk, L.V. (1986): Effect of tamoxifen on pokeweed mitogen stimulated immunoglobulin secretion in vitro. J Clin Lab Immunol, 21(3): 137-9.

Baral, E., Kwok, S., Berczi, I. (1989): Suppression of lymphocyte mitogenesis by tamoxifen. Immunopharmacology, 18(1), 57-62.

Baral, E., Nagy, E., Berczi, I. (1994): Target cell are sensitized for cytotoxic T-lymphocyte-mediated destruction by estradoil and tamoxifen. Int J Cancer, 58(1): 64-8.

Baral, E., Nagy, E., Kwok, S., McNicol, A., Gerrard, J., Berczi, I. (2000): Suppression of lymphocyte mitogenesis by tamoxifen: studies on protein kinase $\mathrm{C}$, calmodulin and calcium. Neuroimmunomodulation, 7(2), 68-76.

Bayoumi, M.T., Zaafarany, R.M., and Ramadan, A.G. (1979): Changes in mice liver after long-term administration of diazinon. Al-Azhar Med. J. 8(2), 263-266.

Blaylock, B.L., Abdel-Nasser, M., McCarty, S.M., Knesel, J.A., Tolson, K.M.,Ferguson, P.W. and H.M. Mehendale. (1995): Suppression of cellular immune responses in BALB/c mice following oral exposure to permethrin. Bulletin of Environmental Contamination and Toxicology, 54:768-774.

Boyum, A.(1968): Separation of leukocytes from blood and bone marrow. Scand. J. Clin. Lab. Invest., 21: Supp, 97:7.

Bradburry, J. E., Forshan, P. J., Gray, A. J., Ray, D. E. (1983): The action of mephenesin and other agents on the effect produced by two neurotoxic pyrethroids in intact and spinal rat. Neuropharmacology 22, 907-914.

Caballero, F., Gerez, E., Oliveri, L., Falcoff, N., Batlle, A., Vazquez, E. (2001): On the promoting action of tamoxifen in a model of hepatocarcinogenesis induced by $p$ dimethylaminoazobenzene in $C F 1$ mice. The International Journal of Biochemistry \& Cell Biology, 33, 681-690.

Cantabrana, B. and Hidalgo, A. (1992): Effects of nonsteroidal antiestrogens in the in vitro rat uterus. Pharmacology; 45: 329-37.

Chen, H., Xiao, J., Hu, G., Zhou, J., Xiao, H., Wang, X. (2002): Estrogenicity of organophosphorus and pyrethroid pesticides. J Toxicol. Environ. Health, 65(19): 1419-35.

Clapp, M. J. L., Banham, P. B., Chart, I. S., Glaister, J., Gore, C., Moyes, A. (1977): PP557: 28 day feeding study in rats (unpublished report submitted to WHO). In: Permethrin IPCS Environmental Health Criteria 94. WHO, Geneva, p.68.

Clemens, L. E., Siiteri, P. K., Stites, D. P. (1978): Mechanism of immunosuppression of progesterone of natural lymphocyte activation during pregnancy. J Immunol., 122(5): 1978-1985.

Cohen, J. H. D., Danel, L., Cordier, G. et al. (1983): Sex steroid receptors in peripheral $\mathrm{T}$ cell: Absence of androgen receptors to OKT8- positive cells. J Immunol., 131: 27672771.

Colley, D. G., Todd, C. W., Lewis, F. A., and Goodgame, R. W. (1979): Immune responses during human 
Schistosomiasis mansoni. VI. In vitro nonspecific suppression of phytohemagglutinin responsiveness induced by exposure to certain schistosomal preparations. J. Immunol., 122: 14471453 .

Cook-Mills, J. M., Cohen, R. L., Perlan, R. L., Chambers, D. A. (1995): Induction of lymphocyte activation by catecholamines: evidence for a non classical mechanism of catecholamine action. Immunology 85, 544-549.

Cremer, J. E. and Seville, M. P. (1982): Comparative effects of two pyrethroids deltamethrin and cismethrin on plasma catecholamines and on blood glucose and lactate. Toxicol. Appl. Pharmacol. 66, 124-133.

Csaba, G. and Inczefi-Gonda, A. (2000): Effect of neonatal treatment with mifepristone or tamoxifen on the binding capacity of the thymic glucocorticoid or uterine estrogen receptor of adult rats: data on mechanism of hormonal imprinting. Life Sci, 67(20):2531-7.

Dacie, J.V. and Lewis, S.M. (1991): Practical Haematology. Churchill Livingstone UK, $7^{\text {th }}$ Ed.

Davies, R. J. and Magnussen, H. (1997): Is pollution a cause or a trigger for the increase in allergic disease? Preface. Allergy 38(Suppl.), 5-6.

Dési, I., Dobronyi, I., Varga, L. (1986): Immuno-, neuro-, and general toxicologic animal studies on a synthetic pyrethroid: Cypermethrin. Ecotoxicol Environ Saf 12:220232

Desi, I., Varga, L., Dobronyi, I., Szklenarik, G. (1985): Immuno-toxicological investigation of the effect of pesticide; cypermethrin. Archiv Toxicol , 8 :305 - 309 .

Diel, F., Detscher, M., Brock, H., Schrimpf, D., Diel, E., Hoppe, H.W., (1998): Effects of permethrin on human basophils and lymphocytes in vitro. Inflammation Research 47 (suppl. 1), S11-S12.

Diel, F., Horr, B., Brock, H., Savtchenko, H., Mitsche, T., Diel, E. (1999): Pyrethroids and piperonyl-butoxide affect human T-lymphocytes in vitro. Toxicology Letters 107, 6574.

El-Elaimy,I.A., Al-Sharkawi,I.M., and Amer, T. (1990a): Release of Histamine and Cortisol in the blood of albino rats under stress of intoxication with an $\alpha$-cyano or a benzyl pyrethroid derivatives. J. Egypt. Soc. Toxicol. 5: 75-84.

Fishelson, Z., Shlanger, S., Bomstein, Y., Evans, C.H. (1992): The human lymphokine leukoregulin induce cell resistance to complement-mediated lysis. Immunol Lett, 32(1):35-41.

Forsberg, J.G. (1984): Short term and long term effect of estrogen on lymphoid tissues and lymphoid cells with some remarks on the significance of carcenogenesis. Arch. Toxicol., $55: 79-80$.

Forsberg, J.G. (2000): Neonatal estrogen treatment and its consequences for thymus development, serum level of autoantibodies to cardiolipin, and the delayed-type hypersensitivity response. J Toxicol Environ Health. 60(3), 185213.

Gabbianelli, R., Falcioni, G., Nasuti, C., Cantalamessa, F. (2002): Cypermethrin-induced plasma membrane perturbation on erythrocytes from rats: reduction of fluidity in the hydrophobic core and in glutathione peroxidase activity. Toxicology 175, 91-101.
Gad, S.C., Dunn, B.J. , Dobbs, D.W. , Reilly, C., Walsh, R.D. (1986): Development and validation of an alternative dermal sensitization test : the mouse ear swelling test (MEST) . Toxicol Appl pharmacol; 84: 93- 114.

Ganong, W. S. (1989): The adrenal medulla and adrenal cortex in "Review of Medical Physiology" $14^{\text {th }}$ ed. Publisher Appleton \& Lange, 301-325.

Gassner, B., Wuthrich, A., Scholtysik, G., Solioz, M. (1997): The pyrethroids permethrin and cyhalothrin are potent inhibitors of the mitochondrial complex I. Journal of Pharmacology and Experimental Therapeutics 281, 855-860.

Gill-Sharma, M.K., Balasinor, N., Parte, P. (2001): Effect of intermittent treatment with tamoxifen on reproduction in male rats. Asian J Androl. 3(2), 115-9.

Grey, A.B., Evans, M.C., Kyle, C., Reid, I.R. (1997): The anti-oestrogen tamoxifen produces haemodilution in normal postmenopausal women. J Intern Med. 242(5), 383-8.

Hadnagy, W., Leng, G., Sugiri, D., Ranft, U., Idel, H. (2003): Pyrethroids used indoors-immune status of human exposed to pyrethroids following a pest control operation-a one year follow-up study. Int. J. Environ. Health, 206, 93-102.

Hart, D., Banham, P. B., Gore, C. W., Pratt, I., Weight, T. M. (1977): PP557: liver hyperthropy study in rats-dietary administration over 26 weeks (unpublished report submitted to WHO). In: Permethrin IPCS Environmental Health Criteria 94. WHO, Geneva, p.70.

Hassan, N. R. A., Mahgoub, A. E. S., and Ali, F. R. (1985): Morphopathological alteration due to chronic toxicity by cyolane in goats. Proc. Zool. Soc. A. R. E. 8, 58-66.

Hext, P.M., Brammer, A., Chalmers, D.T., et al. (1986): PP321: 1 Year oral dosing study in dogs. ICI Amers Inc. OTS0545310.

Hoellinger, H., Lecorsier, A., Sonner, M., Leger, C., DoCao-Tang, Nguyen-Hoang-Nam,(1987): Cytotoxicity, cytogenotoxicity, allergenicity tests on certain pyrethroids. Drug Chem Toxicol, 10: 291-310.

Institoris, L., Undeger, U., Siroki, O., Nehez, M., Desi, I. (1999a):Comparison of detection sensitivity of immuno- and genotoxicological effects of subacute cypermethrin and permethrin exposure in rats. Toxicology, 137: 47-55.

Institoris, L., Siroki, O., Undeger, U., Desi, I., Nagymajtenyi, L. (1999b): Immunotoxicological effects of repeated combined exposure by cypermethrin and heavy metals lead and cadmium in rats. International Journal of immunopharmacology 21, 735-743.

IRIS. (2001a): Chronic health hazard assessments for noncarcinogenic effects: Permethrin. U.S. Environmental Protection Agency. Integrated Risk Information System. Http://www.epa.gov/ ngispgm3/iris/subst/0185.htm. February 8,2001

IRIS. (2001b): Chronic health hazard assessments for noncarcinogenic effects: Resmethrin. U.S. Environmental Protection Agency. Integrated Risk Information System. Http://www.epa.gov/ngispgm3/iris/subst/0343.htm. April 10, 2001.

Ishmael, J. and Litchfield, M. H. (1988): Chronic toxicity and carcinogenic evaluation of permethrin in rats and mice. Fundam Appl Toxicol 11:308-322. 
Jarvinen, L.S., Pyrhonen, S., Kairemo, K.J., Paavonen, T. (1996): The effect of antioestrogens on cytokine production in vitro. Scand J Immunol , 44(1):15-20.

Kadota, T., Miyamoto, J., Ito, N. (1975): Six-month subacute oral toxicity of NRDC in Sprague-Dawley rats (unpublished report submitted to WHO). In: Permethrin IPCS Environmental Health Criteria 94. WHO, Geneva, p.70.

Kale, M., Rathore, N., John, S., Bhatnagar, D. (1999): Lipid peroxidative damage on pyrethroid exposure and alterations in antioxidant status in rats erythrocytes: a possible involvement of reactive oxygen species .Toxicol Lett., 105 (3): 197-205.

Killen, J. C., Rapp, W. R. (1976): A three month oral toxicity study of FMC 33297 in rats (unpublished report submitted to WHO). In: Permethrin IPCS Environmental Health Criteria 94. WHO, Geneva, p.69.

Kobayashi, M., Fitz, L., Ryan, M. (1989): Identification and purification of natural killer cell stimulatory factor (NKSF) a cytokine with multiple biologic effects on human lymphocytes. J Exp Med, 170, 827-845.

Komi, J. and Lassile, O. (2000): Nonsteroidal anti-estrogens inhibit the functional differentiation of human monocytederived dendritic cells. Blood, 95 (9), 2875-2882.

Kosaka, A. and Yamashita, A. (1992): Experimental study of combination medical endocrine therapy on DMBA-induced mammary tumor, with special reference to the effect of drugdose on various factors. Gan To Kagaku Ryoho. 19(1), 75-81.

Kostrzewska, A., Laudanski, T., Batra, S. (1997): Potent inhibition by tamoxifen of spontaneous and agonist-induced contractions of the human myometrium and inframyometrial arteries. Am J Obstet Gynecol; 176: 381-6.

Krechniak, J., Wrzesniowska, K. (1991): Effects of pyrethroid insecticides on hepatic microsomal enzymes in rats. Environ. Res. 55(2), 129-134.

Krishnappa, H., Honnegowda, Suresh T.P., Jayakumar,K., Narayana, K. (1999): Effects of lambda cyhalothrin , a synthetic pyrethroid insecticide on certain defense mechanisms and immune response in male rats. Indian Vet. J., $76: 506-510$.

Kuiper, G., Shughrue, P., Merchenthaler, I., Gustafsson, J.A. (1998): The oestrogen receptor $\beta$ subtype: A novel mediator of oestrogen action in neuro -endocrine systems. Front Neuroendocrinol; 19: 253-86.

Leitner, G., Landsman, T., Blum, O., Zaltsmann, N., Heller, E.D. (1996): Effects of gonadal steroids and their antagonists on the humoral immune response of immuneselected broiler chicks. Poult Sci ,75(11): 1373-82.

Litchfield, J. T., Wilcoxon Jr F. (1949): A simplified method of evaluating dose-effect experiments. J Pharmacol Exp Ther , 96, 99- 113.

Lowry, O. H., Rosenbrough, N. J., Farr, A. L., and Randall, R. J. (1951): Protein measurement with the Folin phenol reagent. J. Biol.Chem., 193: 265-275.

Lukac, J., Kusic, Z., Kordic, D., Koncar, M., Bolanca. A. (1994): Natural killer cell activity, phagocytosis, and number of peripheral blood cells in breast cancer patients treated with tamoxifen. Breast Cancer Res Treat; 29(3):179-85.

Lukowicz-Ratajczak, J., Krechniak J (1991): Wplyw dekametryny na uklad immunologiczny. Cz. I Dzialanie immunosupresyjne. Bromat Chem Toksykol, 1, 57-61.
Lukowicz-Ratajczak, J. and J. Krechniak. (1992a): Effects of deltamethrin on the immune system in mice. Environmental Research, 59(2):467-475.

Lukowicz-Ratajczak, J., Krechniak, J., Englot, B. (1992b): Wplyw delmetryny na uklad immunologiczny .Cz. II. Wplyw na odpowiedz humoralna i komorkowa.Bromat Chem Toksykol, 3, 263-266.

Luty, S., Maj, A. (1998a): Wplyw alphacypermetryny na poziom wybranych cytokin osoczowych u myszy: IX Zjazd Polskiego Towarzystwa Immunologii DoŚwiadczalnej I Klinicznej Warszawa, 16-18.09.1998. Materialy zjazdowe, SGGW, Warszawa, ,p.304.

Luty, S., Latuszynska, J., Przylepa, E. (1998c): Immunotoksycznosc parakwatu, dichlorfosu I alphacypermetryny wchlaaniaych przez skore. Brom Chem Toksykol, 3, 259-263.

Luty,S., Latuszynska, J.,Obuchowska-Przebirowska, D., Tokarska, M., Haratym-Maj, A. (2000): Subacute toxicity of orally applied alpha-cypermethrin in swiss mice. Ann Agic Environ Med 7: 33-41.

MacGregor, J.I., Jordan, V. (1998): Basic guide to the mechanisms of antiestrogen action. Pharmacol Rev; 50:15196.

Madsen, C., Cleasson, M.H., Ropke, C. (1996): Immunotoxicity of the pyrethroid insecticides delthamethrin and alpha-cypermethrin. Toxicology, 3, 219-227.

Mallmann, P., Dietrich, K., Krebs, D. (1990): Effect of tamoxifen and high-dose medroxyprogesterone acetate (MPA) on cell-mediated immune functions in breast cancer patients. Methods Find Exp Clin Pharmacol , 12(10):699-706.

Mancini, G., carbonara, A.O. et al. (1965): Immunochemical quantitation of antigens by single radial immunodiffusion. immunochem. 2,235-254.

Mannerstrom, M., Maenpaa, H., Toimela, T., Salminen, L., Tahti, H. (2001): The phagocytosis of rod outer segments is inhibited by selected drugs in retinal pigment epithelial cell cultures. Pharmacol Toxicol, 88(1):27-33.

Markert, M., Andrews, P. C., and Babior, B. M. (1984): Measurement of $\mathrm{O}_{2}^{-}$production by human neutrophils. The preparation and assay of NADPH oxidase containing particles from human neutrophils. Meth. Enzymol., 105: 358-65.

Metker, L. W., Angerhofer, R. A., Pope, C. R., Swentzel, K. C. (1977): Toxicology evaluation of 3-(phenoxyphenol)2,2-dimethylcyclopropane -carboxylate (permethrin) (unpublished report submitted to WHO). In: Permethrin IPCS Environmental Health Criteria 94. WHO, Geneva, p.68.

Moya-Quiles, M. R., Munoz-Delgado, E., Vidal, C. J. (1996): The pyrethroid insecticide deltamethrin modifies the thermotropic properties and lipid packing order of model membrane. Chem. Phys. Lipids 83, 61-69.

Nguyen, M.C., Stewart, R.B., Banerji, M.A, Gordon, D.H., Kral, J.G. (2001): Relationships between tamoxifen use, liver fat and body fat distribution in women with breast cancer. Int $\mathrm{J}$ Obes Relat Metab Disord. 25(2), 296-8.

Oge, A., Sezer, E.D., Ozgonul, M., Bayraktar, F. and Sozmen, E.Y. (2003): The effects of estrogen and raloxifene treatment on the antioxidant enzymes and nitrite-nitrate levels in brain cortex of ovariectomized rats. Neurosci. Lett., $338(3): 217-20$.

Oruc, E.O. and Uner, N. (2000): Combined effects of 2,4-D and azinphosmethyl on antioxidant enzymes and lipid 
peroxida-tion in liver of Orechromis niloticus . Comp. Biochem. Physiol. Part C 127, 291-296.

Paavonen, T., Aronen, H., Pyrhonen, S., Hajba, A., Andersson, L.C. (1991): The effects of anti-estrogen therapy on lymphocyte function in breast cancer patients. APMIS, 99(2), 163-170.

Paget, Barnes. (1964): Evaluation of drug activities. In: Laurence, Bacharach eds. Pharmacometrics. New York. Academic Press, 1.

Parker, C.M., Patterson, D.R., Van Gelder, G.A., et al. (1984a): Chronic toxicity and carcinogenicity evaluation of fenvalerate in rats. J Toxicol Environ Health 13:83-97.

Parker, C.M., Piccirillo, V.J., Kurtz, S.L., et al. (1984b): Six-month feeding study of fenvalerate in dogs. Fundam Appl Toxicol 4:577-586.

Pasqualini, J.R., Gulino, A., Sumida, C., Screpanti, I. (1984): Anti-estrogens in fetal and newborn target tissue. J Steroid Biochem, 20(1):121-8.

Pauluhn, J. (1996): Risk assessment of pyrethroids following indoor use. Toxicol .Lett. 88, 339-348.

Pigeolet, E., Carbisier, P., Houbion, A., Lambert, D., Michiels, C., Raes, M., Zachary, M., Remacle, J. (1990): Glutathione peroxidase, superoxide dismutase, and catalase inactivation by peroxides and oxygen derived free radicals, Mech. Ageing Dev. 51 ,283-297.

Punareewattana, K., Smith, B.J., Blaylock, B.L., Longstreth, J., Snodgrass, H.L., Gogal, R.M., Prater, R.M., Holladay, S.D. (2001): Topical permethrin exposure inhibits antibody production and macrophage function in C57b1/6N mice. Food and Chemical Toxicology 39: 133-139.

Purdom, C. E. (1983): Progesterone-prostaglandin balance influences lymphocyte functions in relation to pregnancy. Am J Reprod Immunol., 4: 139-141.

Ray, D. E. Jr, (1991): Pesticides derived from plants and other organisms. In: Hayes, W. Y. Jr, (Eds.), Handbook of Pesticide Toxicology. Academic Press, San Diego, CA, pp. 585-636.

Ray, D. E. and Cremer, J. E. (1979): The action of decamethrin (a synthetic pyrethroid) on the rat. Pestic. Biochem. Physiol. 10, 333-340.

Rhodes, C., Jones, B. K., Croucher, A., Huston, D. H., Logan, C. J., Hopkins, R., Hall, B. E., Vickers, J. (1984): The bioaccumulation and biotransformation of cis, trans cypermethrin in the rat. Pestic. Sci. 15, 471-480.

Sabbioni, M. E. E., Castiglione, M., Hurny, C., Siegrist, H., Bacchi, M., Bernhand, J., Thurlimann, B., Bonnefoi, H., Perey, L., Goldhirsch, A., Senn, H. (1999): Interaction of tamoxifen with concurrent cytotoxic adjuvant treatment affects lymphocytes and lymphocyte subsets counts in breast cancer patients. Supportive Care in Cancer, 7(3), 149-153.

Santoni, G., Cantalamassa, F., Cavanga, R., Spreghini, E., Piccoli, M. (1998): Cypermethrin-induced alternation of thymocyte distribution and functions in prenatally - exposed rats. Toxicology, 125, 67-78.

Santoni, G., Cantalamassa, F., Spreghini, E., Sagretti, O., Staffolani, M., Piccoli, M. (1999): Alterations of T cell distribution and functions in prenatally cypermethrin exposed rats: possible involvement of catecholamines. Toxicology, 138: $175-187$
Santoni, G., Cantalamessa, F., Mazzucca, L., Romagnoli, S., Piccoli, M. (1997): Prenatal exposure to cypermethrin modulates rat NK cell cytotoxic functions. Toxicology, 120:231-242.

Scambia, G., Panici, P.B., Maccio, A., Castelli, P., Serri, F., Mantovani, G., Massidda, B., Lacobelli, S., Del Giacco, S., Mancuso, S. (1988): Effects of antiestrogen and progestin on immune functions in breast cancer patients. Cancer , 61(11):2214-8

Schoenig, G.P. (1995): Mammalian toxicology of pyrethrum extract. In: Casida JE, Quistad GB, eds. Pyrethrum Flowers: Production, Chemistry, Toxicology, and Uses. New York: Oxford University Press, 249-257.

Sfikakis, P.P., Kostomitsopoulos, N., Kittas, C., Stathopoulos, J., Karayannacos, P., Dellia-Sfikakis, A., Mitropoulos, D. (1998): Tamoxifen exerts testosteronedependent and independent effects on thymic involution. Int $\mathrm{J}$ Immunopharmacol ,20(6):305-12.

Siroki, O., Institoris, L., Tator, E., Desi, I. (1994): Immunotoxicological investigation of SCMF, a new pyrethroid pesticide in mice. Hum. Exp. Toxicol. 13, 337-343.

Stanley, L.A., Carthew, P., Davies, R., Higginson, F., Martin, E., $\quad$ Styles, $\quad$ J.A..(2001): Delayed effects of tamoxifen in hepatocarcinogenesis-resistant Fischer 344 rats as compared with susceptible strains. Cancer Lett., 171(1), 27-35.

Stelzer, K.J. and M.A. Gordon. (1984): Effects of pyrethroids on lymphocyte mitogenic responsiveness. Research Communications in Chemical Pathology and Pharmacology, 46(1):137-150.

Styles, J.A., Davies, R., Fenwick, S., Walker, J., White, I.N., Smith, L.L. (2001): Tamoxifen mutagenesis and carcinogenesis in livers of lambda/lacI transgenic rats: selective influence of Phenobarbital promotion. Cancer Lett. 162(1), 117-22.

Surralles, J., Xamena, N., Creus, A., Catalan, J., Norppa, H., Marcos, R. (1995): Induction of micronuclei by five pyrethroids insecticides in whole-blood and isolated human lymphocyte cultures. Mutation Research, 341, 169-184.

Tamang, R.K., G.J. Jha, M.K. Gupta, H.V.S. Chauhan, and B.K. Tiwary. (1988): In vivo immunosuppression by synthetic pyrethroid (cypermethrin) pesticides in mice and goats. Veterinary Immunology and Immunopathology, 19:299-305.

Thangaraju, M., Vijayalakshmi, T., Sachdanandam, P. (1994): Effect of tamoxifen on lipid peroxide and antioxidative system in postmenopausal women with breast cancer. Cancer , 1;74 (1):78-82.

Thangaraju, M., Ezhilarasi, R., Sachdanandam, P. (1995): Effect of tamoxifen on erythrocyte membrane lipid, lipid peroxide, and antioxidative enzymes in breast cancer women. Cancer Biochem. Biophys., 14(4), 279-302.

Timothy, B.H., David, A.M., Pamela, A.F. and George, T.R. (1997): A Cytotoxicity Evaluation of Antimicrobial and Non-Microbial Wound Cleansers. Derma Sciences, 5(1): 1-6.

Toimela, T., Tahti, H., Salminen, L. (1995): Retinal pigment epithelium cell culture as a model for evaluation of the toxicity of tamoxifen and chloroquine. Ophthalmic Res; 27 Suppl 1:150-3.

Varshneya, C.,T. Singh, L.D. Sharma, H.S. Bahga, and S.K. Garg. (1992): Immunotoxic responses of cypermethrin, 
a synthetic pyrethroid insecticide in rats. Indian Journal of Physiological Pharmacology, 36(2):123-126.

Watanabe, T., Inoue, S., Ogawa, S., Ishii, Y., Hiroi, H. (1997): Agonistic effect of tamoxifen is dependent on cell type ,ERE- promotor context, and oestrogen receptor subtype:
Functional difference between oestrogen receptors $\alpha$ and $\beta$. Biochem Biophys Res Commun; 236:140-45.

Wu, W. M., Suen, J. L., Lin, B. F., Chiang, B. L. (2000): Tamoxifen alleviates disease severity and decreases double negative $\mathrm{T}$-cell in autoimmune MRL-1pr mice. Immunology, 100(1), 110-118.

Table (1): Relative organ weights in male Wistar rats chronically treated with pyrethroids for 30 and 60 days and after modulation with tamoxifen.

\begin{tabular}{|c|c|c|c|c|c|c|c|}
\hline \multirow{3}{*}{ Parameter } & \multirow{3}{*}{ Groups } & \multicolumn{4}{|c|}{ Period } & \multirow{2}{*}{\multicolumn{2}{|c|}{$\begin{array}{l}\text { Independent } \\
\text { Samples Test }\end{array}$}} \\
\hline & & \multicolumn{2}{|c|}{ After 30 days } & \multicolumn{2}{|c|}{ After 60 days } & & \\
\hline & & Mean & $\pm S D$ & Mean & $\pm S D$ & $\mathbf{T}$ & Sig. (2-tailed) \\
\hline \multirow{8}{*}{$\begin{array}{l}\text { Spleen wt./Body weight } \\
\left(\mathrm{g} \times 10^{-3}\right)\end{array}$} & Control & $2.46^{\mathrm{a}}$ & \pm 0.10 & $2.70^{a b}$ & \pm 0.03 & & \\
\hline & Permethrin & $2.72^{b}$ & \pm 0.10 & 2.69 ab & \pm 0.18 & 0.339 & 0.743 \\
\hline & Cypermethrin & $2.60^{a b}$ & \pm 0.04 & $2.63^{a b}$ & \pm 0.06 & 0.931 & 0.379 \\
\hline & Permethrin + Tamoxifen & $2.61^{\mathrm{ab}}$ & \pm 0.09 & $2.78^{a}$ & \pm 0.13 & 2.450 & $0.040^{*}$ \\
\hline & $\begin{array}{l}\text { Cypermethrin + } \\
\text { Tamoxifen } \\
\end{array}$ & $3.83^{c}$ & \pm 0.26 & $2.51^{b}$ & \pm 0.13 & 9.696 & $0.000^{* * *}$ \\
\hline & Tamoxifen & $2.45^{\mathrm{a}}$ & \pm 0.22 & $2.61^{\mathrm{ab}}$ & \pm 0.24 & 1.118 & 0.296 \\
\hline & ANOVA & 44.33 & & 1.927 & & & \\
\hline & $\mathbf{P}$ & $0.000^{* * *}$ & & 0.127 & & & \\
\hline \multirow{8}{*}{$\begin{array}{l}\text { Liver wt./Body weight ( } \\
\text { g } \times 10^{-3} \text { ) }\end{array}$} & Control & $32.04^{\mathrm{a}}$ & \pm 0.81 & $31.42^{\mathrm{a}}$ & \pm 0.87 & & \\
\hline & Permethrin & $35.18^{\mathrm{b}}$ & \pm 0.08 & $28.34^{\mathrm{b}}$ & \pm 0.89 & 17.100 & $0.000^{* \star *}$ \\
\hline & Cypermethrin & $33.60^{c}$ & \pm 0.50 & $29.08^{b}$ & \pm 0.26 & 17.951 & $0.000^{* * *}$ \\
\hline & Permethrin + Tamoxifen & $38.44^{d}$ & \pm 0.05 & $34.92^{c}$ & \pm 0.43 & 18.300 & $0.000^{* * *}$ \\
\hline & $\begin{array}{l}\text { Cypermethrin + } \\
\text { amoxifen }\end{array}$ & $35.32^{b}$ & \pm 0.19 & $31.62^{\mathrm{a}}$ & \pm 0.70 & 11.375 & $0.000^{* * *}$ \\
\hline & Tamoxifen & $34.92^{\mathrm{b}}$ & \pm 0.86 & $35.64^{c}$ & \pm 2.20 & 0.681 & 0.525 \\
\hline & ANOVA & 79.864 & & 36.970 & & & \\
\hline & $\mathbf{P}$ & $0.000^{* * *}$ & & $0.000^{* * *}$ & & & \\
\hline \multirow{8}{*}{$\begin{array}{l}\text { Testes wt./Body weight } \\
\left(\mathrm{g} \times 10^{-3}\right)\end{array}$} & Control & $10.83^{a}$ & \pm 0.20 & $12.12^{\mathrm{a}}$ & \pm 0.73 & & \\
\hline & Permethrin & $9.92^{b}$ & \pm 0.34 & $11.54^{b}$ & \pm 0.26 & 8.422 & $0.000^{* * *}$ \\
\hline & Cypermethrin & $10.98^{a}$ & \pm 0.36 & $10.52^{c}$ & \pm 0.22 & 2.431 & $0.041^{*}$ \\
\hline & Permethrin + Tamoxifen & $9.26^{c}$ & \pm 0.47 & $2.39^{d}$ & \pm 0.05 & 32.357 & $0.000^{* * *}$ \\
\hline & $\begin{array}{l}\text { Cypermethrin + } \\
\text { Tamoxifen } \\
\end{array}$ & $10.70^{a}$ & \pm 0.26 & $2.93^{\mathrm{de}}$ & \pm 0.29 & 37.989 & $0.000^{* * *}$ \\
\hline & Tamoxifen & $11.30^{\mathrm{a}}$ & \pm 0.50 & $3.14^{\mathrm{e}}$ & \pm 0.65 & 20.989 & $0.000^{\star * *}$ \\
\hline & ANOVA & 17.337 & & 585.73 & & & \\
\hline & $\mathbf{P}$ & $0.000^{* * *}$ & & $0.000^{* * *}$ & & & \\
\hline \multirow{8}{*}{$\begin{array}{l}\text { Thymus wt./Body weight } \\
\left(\mathrm{g} \times 10^{-3}\right)\end{array}$} & teontrol & $1.42^{\mathrm{a}}$ & \pm 0.01 & $0.93^{a}$ & \pm 0.02 & & \\
\hline & Permethrin & $1.12^{b}$ & \pm 0.01 & $0.76^{\mathrm{b}}$ & \pm 0.03 & 25.314 & $0.000^{* * *}$ \\
\hline & Cypermethrin & $1.08^{b}$ & \pm 0.11 & $0.99^{\mathrm{a}}$ & \pm 0.04 & 1.851 & 0.123 \\
\hline & Permethrin + Tamoxifen & $1.39^{\mathrm{a}}$ & \pm 0.10 & $1.46^{c}$ & \pm 0.05 & 1.298 & 0.231 \\
\hline & $\begin{array}{l}\text { Cypermethrin + } \\
\text { Tamoxifen } \\
\end{array}$ & $1.62^{\mathrm{c}}$ & \pm 0.08 & $1.16^{d}$ & \pm 0.09 & 8.388 & $0.000^{* * *}$ \\
\hline & Tamoxifen & $1.57^{\mathrm{c}}$ & \pm 0.07 & $1.30^{\mathrm{e}}$ & \pm 0.07 & 6.008 & $0.000^{\star * *}$ \\
\hline & ANOVA & 43.367 & & 108.569 & & & \\
\hline & $\mathbf{P}$ & $0.000^{* * *}$ & & $0.000^{* * *}$ & & & \\
\hline
\end{tabular}

Significant * $(P<0.05)$, High significant $* *(P<0.01)$, and Very high significant $* * *(P<0.001)$

ANOVA: Analysis of variance, and SD" Standard deviation

Significant differences between groups calculated by ANOVA and follow up test (LSD)

Means in the same columns assigned with the same letter show insignificant differences between these values. 
Table (2): Total leukocytic count in male Wistar rats chronically treated with pyretheroids for 30 and 60 days and after modulation with tamoxifen.

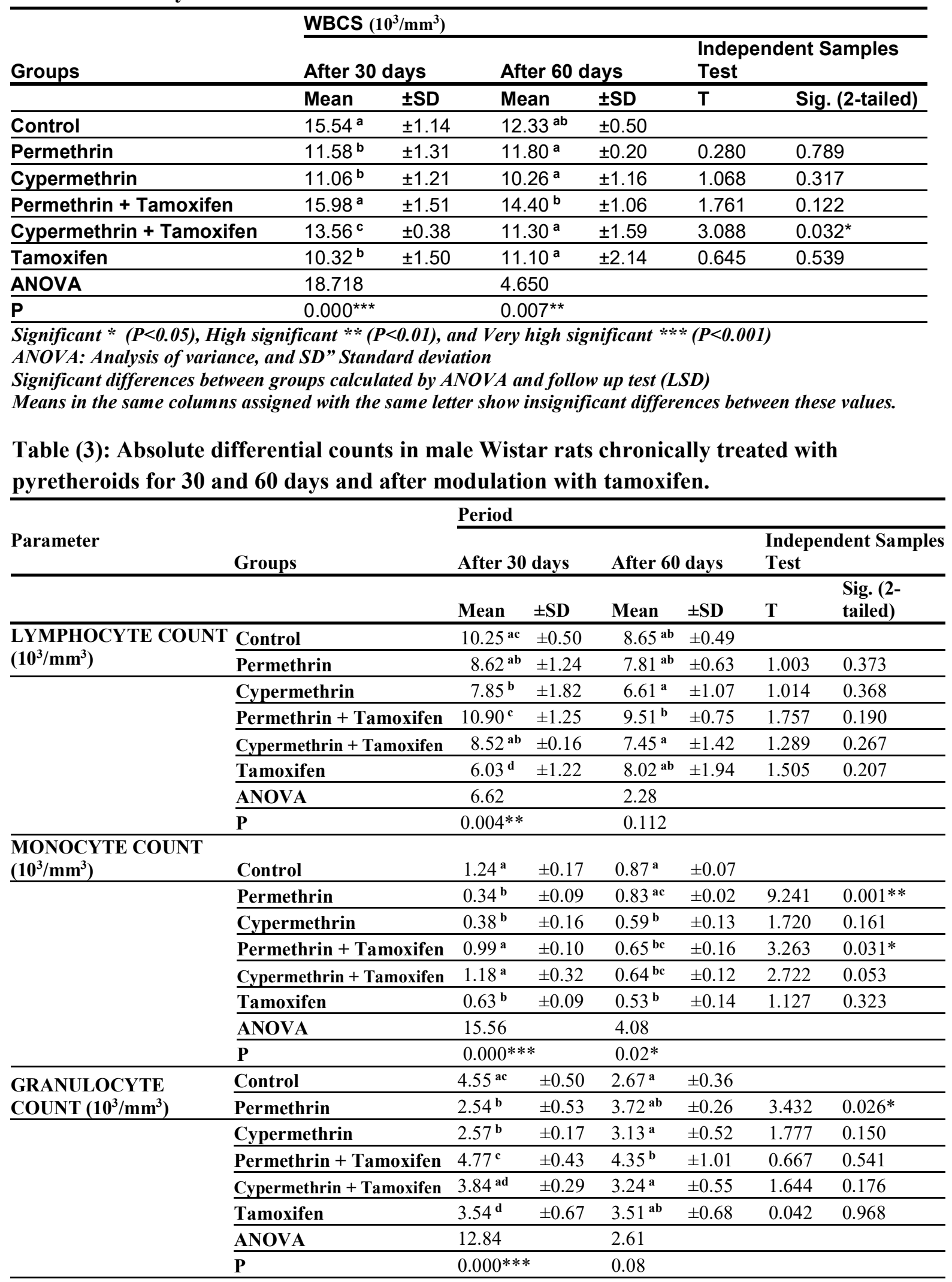


Significant * $(P<0.05)$, High significant $* *(P<0.01)$, and Very high significant $* * *(P<0.001)$

ANOVA: Analysis of variance, and SD" Standard deviation

Significant differences between groups calculated by ANOVA and follow up test (LSD)

Means in the same columns assigned with the same letter show insignificant differences between these values.

Table (4): Lymphoproliferative response to mitogen expressed as stimulation index (SI) in rats chronically treated with pyrethroids for 30 and 60 days and after modulation with tamoxifen.

\begin{tabular}{|c|c|c|c|c|c|c|}
\hline \multirow{3}{*}{ Groups } & \multicolumn{6}{|l|}{ S. INDEX } \\
\hline & \multicolumn{2}{|c|}{ After 30 days } & \multicolumn{2}{|c|}{ After 60 days } & \multicolumn{2}{|c|}{$\begin{array}{l}\text { Independent Samples } \\
\text { Test }\end{array}$} \\
\hline & Mean & $\pm S D$ & Mean & $\pm S D$ & $\mathbf{T}$ & Sig. (2-tailed) \\
\hline Control & $12.81^{\mathrm{a}}$ & \pm 1.04 & $13.38^{\mathrm{a}}$ & \pm 2.41 & & \\
\hline Permethrin & 2.32 be & \pm 0.38 & $4.31^{b}$ & \pm 0.26 & 9.659 & $0.000^{* * *}$ \\
\hline Cypermethrin & $4.62^{c}$ & \pm 0.78 & $2.96^{c}$ & \pm 0.10 & 4.722 & $0.008^{* *}$ \\
\hline Permethrin + Tamoxifen & $1.84^{b}$ & \pm 0.07 & $1.07^{\mathrm{d}}$ & \pm 0.07 & 18.036 & $0.000^{* * *}$ \\
\hline Cypermethrin + Tamoxifen & $3.11^{\mathrm{d}}$ & \pm 0.31 & $1.32^{\mathrm{d}}$ & \pm 0.03 & 12.870 & $0.000^{* * *}$ \\
\hline Tamoxifen & $2.88^{\mathrm{de}}$ & \pm 0.06 & $2.27^{\mathrm{dc}}$ & \pm 0.38 & 3.526 & $0.022^{*}$ \\
\hline ANOVA & 263.167 & & 107.178 & & & \\
\hline$\underline{\mathbf{P}}$ & $0.000^{* * *}$ & & $0.000^{* * *}$ & & & \\
\hline
\end{tabular}

Significant * $(P<0.05)$, High significant $* *(P<0.01)$, and Very high significant $* * *(P<0.001)$

ANOVA: Analysis of variance, and SD" Standard deviation

Significant differences between groups calculated by ANOVA and follow up test (LSD)

Means in the same columns assigned with the same letter show insignificant differences between these values.

Table (5): Phagocytic index in male Wistar rats chronically treated with pyrethroids for 30 and 60 days and after modulation with tamoxifen.

\begin{tabular}{|c|c|c|c|c|c|c|}
\hline \multirow{3}{*}{ Groups } & \multicolumn{6}{|c|}{ PHAGOCYTIC INDEX \% } \\
\hline & \multicolumn{2}{|c|}{ After 30 days } & \multicolumn{2}{|c|}{ After 60 days } & \multicolumn{2}{|c|}{$\begin{array}{l}\text { Independent Samples } \\
\text { Test }\end{array}$} \\
\hline & Mean & $\pm S D$ & Mean & $\pm S D$ & $\mathbf{T}$ & Sig. (2-tailed) \\
\hline Control & $56.40^{a}$ & \pm 2.61 & $39.20^{a}$ & \pm 5.12 & & \\
\hline Permethrin & $24.00^{b}$ & \pm 1.00 & $13.80^{b}$ & \pm 0.84 & 17.493 & $0.000^{* * *}$ \\
\hline Cypermethrin & $20.40^{c}$ & \pm 1.14 & $8.60^{\mathrm{ce}}$ & \pm 1.52 & 13.906 & $0.000^{* * *}$ \\
\hline Permethrin + Tamoxifen & $10.20^{\text {de }}$ & \pm 1.79 & $18.40^{d}$ & \pm 1.14 & 8.644 & $0.000^{* * *}$ \\
\hline Cypermethrin + Tamoxifen & $10.60^{d}$ & \pm 1.14 & $11.40^{b c}$ & \pm 1.34 & 1.016 & 0.339 \\
\hline Tamoxifen & $8.20^{\mathrm{e}}$ & \pm 1.79 & $8.20^{\mathrm{e}}$ & \pm 1.30 & 0.000 & 1.000 \\
\hline ANOVA & 588.840 & & 120.607 & & & \\
\hline $\mathbf{P}$ & $0.000^{* * *}$ & & $0.000^{* * *}$ & & & \\
\hline
\end{tabular}

Significant * $(P<0.05)$, High significant ** $(P<0.01)$, and Very high significant *** $(P<0.001)$

ANOVA: Analysis of variance, and SD" Standard deviation

Significant differences between groups calculated by ANOVA and follow up test (LSD)

Means in the same columns assigned with the same letter show insignificant differences between these values. 
Table (6): Level of immunoglobulin G (IgG) in male Wistar rats chronically treated with pyrethroids for 30 and 60 days and after modulation with tamoxifen.

\begin{tabular}{|c|c|c|c|c|c|c|}
\hline \multirow{3}{*}{ Groups } & \multicolumn{6}{|c|}{ IgG CONCENTRATION (mg/L) } \\
\hline & \multicolumn{2}{|c|}{ After 30 days } & \multicolumn{2}{|c|}{ After 60 days } & \multicolumn{2}{|c|}{$\begin{array}{l}\text { Independent Samples } \\
\text { Test }\end{array}$} \\
\hline & Mean & $\pm S D$ & Mean & $\pm S D$ & $\mathbf{T}$ & Sig. (2-tailed) \\
\hline Control & $2720.00^{a}$ & \pm 169.71 & $2720.00^{a}$ & \pm 169.71 & & \\
\hline Permethrin & $2164.00^{b}$ & \pm 131.45 & $1678.00^{b}$ & \pm 120.50 & 6.094 & $0.000^{* * *}$ \\
\hline Cypermethrin & $2032.00^{b}$ & \pm 225.10 & $2164.00^{c}$ & \pm 131.45 & 1.132 & 0.290 \\
\hline Permethrin + Tamoxifen & $3876.00^{c}$ & \pm 142.41 & $3616.00^{d}$ & \pm 142.41 & 2.887 & $0.020^{*}$ \\
\hline Cypermethrin + Tamoxifen & $3980.00^{c}$ & \pm 183.85 & $3720.00^{d}$ & \pm 260.00 & 1.826 & 0.105 \\
\hline Tamoxifen & $3512.00^{d}$ & \pm 116.28 & $3616.00^{d}$ & \pm 142.41 & 1.265 & 0.242 \\
\hline ANOVA & 134.742 & & 133.785 & & & \\
\hline $\mathbf{P}$ & $0.000^{* * *}$ & & $0.000^{* * *}$ & & & \\
\hline
\end{tabular}

Significant * $(P<0.05)$, High significant $* *(P<0.01)$, and Very high significant $* * *(P<0.001)$

ANOVA: Analysis of variance, and SD" Standard deviation

Significant differences between groups calculated by ANOVA and follow up test (LSD)

Means in the same columns assigned with the same letter show insignificant differences between these values.

Table (7): Catalase activity in male Wistar rats chronically treated with pyrethroids for 30 and 60 days and after modulation with tamoxifen.

\begin{tabular}{|c|c|c|c|c|c|c|}
\hline \multirow{3}{*}{ Groups } & \multicolumn{6}{|c|}{ CATALASE ACTIVITY $\left(10^{-3} \mathrm{U} / \mathrm{mg}\right.$ protein / Sec. $)$} \\
\hline & \multicolumn{2}{|c|}{ After 30 days } & \multicolumn{2}{|c|}{ After 60 days } & \multicolumn{2}{|c|}{$\begin{array}{l}\text { Independent Samples } \\
\text { Test }\end{array}$} \\
\hline & Mean & $\pm S D$ & Mean & $\pm S D$ & $\mathbf{T}$ & Sig. (2-tailed) \\
\hline Control & $16.87^{\mathrm{a}}$ & \pm 2.82 & $17.22^{\mathrm{a}}$ & \pm 2.96 & & \\
\hline Permithrin & $12.76^{\mathrm{b}}$ & \pm 1.88 & $13.37^{b}$ & \pm 2.23 & 0.362 & 0.736 \\
\hline Cypermethrin & $5.78^{c}$ & \pm 0.85 & $4.67^{c}$ & \pm 0.81 & 1.639 & 0.177 \\
\hline Permithrin + Tamoxifen & $10.35^{b}$ & \pm 1.40 & $9.87^{d}$ & \pm 1.03 & 0.475 & 0.660 \\
\hline Cypermithrin + Tamoxifin & $5.47^{c}$ & \pm 0.49 & $5.52^{c}$ & \pm 0.77 & 0.095 & 0.929 \\
\hline Tamoxifin & $7.08^{c}$ & \pm 1.01 & $5.81^{c}$ & \pm 0.43 & 2.012 & 0.115 \\
\hline ANOVA & 23.637 & & 28.202 & & & \\
\hline $\mathbf{P}$ & $0.000^{* * *}$ & & $0.000^{* * *}$ & & & \\
\hline
\end{tabular}

Significant * $(P<0.05)$, High significant ** $(P<0.01)$, and Very high significant $* * *(P<0.001)$

ANOVA: Analysis of variance, and SD" Standard deviation

Significant differences between groups calculated by ANOVA and follow up test (LSD)

Means in the same columns assigned with the same letter show insignificant differences between these values. 
Table (8A): Contact hypersensitivity response measured as relative ear thickness (RET) in male Wistar rats chronically treated with permethrin for 30 and 60 days and after modulation with tamoxifen.

\begin{tabular}{|c|c|c|c|c|c|c|}
\hline \multirow[b]{3}{*}{ Groups } & \multicolumn{6}{|c|}{ Relative Ear Thickness \% } \\
\hline & \multicolumn{2}{|c|}{ After 00 day } & \multicolumn{2}{|c|}{ After 30 days } & \multicolumn{2}{|c|}{ After 60 days } \\
\hline & Mean & \pm SD & Mean & \pm SD & Mean & \pm SD \\
\hline Control & $9.22^{a}$ & \pm 0.89 & $10.68^{a}$ & \pm 0.62 & $14.37^{\mathrm{a}}$ & \pm 1.81 \\
\hline Permethrin & $57.16^{\mathrm{b}}$ & \pm 2.87 & $36.06^{\mathrm{b}^{\star \star \star}}$ & \pm 1.43 & $36.85^{b^{\star *}}$ & \pm 4.15 \\
\hline Permethrin + Tamoxifen & $60.77^{b}$ & \pm 1.58 & $40.60^{\mathrm{c}^{\star \star \star}}$ & \pm 1.87 & $39.84^{b^{\star \star \star}}$ & \pm 3.09 \\
\hline Tamoxifen & $22.36^{c}$ & \pm 1.89 & $14.85^{\mathrm{d}}$ & \pm 4.06 & $19.91^{\mathrm{a}}$ & \pm 2.38 \\
\hline ANOVA & 518.86 & & 147.18 & & 52.49 & \\
\hline $\mathbf{P}$ & $0.000^{* * *}$ & & $0.000^{* * *}$ & & $0.000^{* * *}$ & \\
\hline
\end{tabular}

Significant $*(P<0.05)$, High significant $* *(P<0.01)$, and Very high significant $* * *(P<0.001)$ ANOVA: Analysis of variance, and SD" Standard deviation Significant differences between groups calculated by ANOVA and follow up test (LSD)

Means in the same columns assigned with the same letter show insignificant differences between these values.

Table (8B): Contact hypersensitivity response measured as relative ear thickness (RET) in male Wistar rats chronically treated with cypermethrin for 30 and 60 days and after modulation with tamoxifen.

\begin{tabular}{|c|c|c|c|c|c|c|}
\hline \multirow[b]{3}{*}{ Groups } & \multicolumn{6}{|c|}{ Relative Ear Thickness \% } \\
\hline & \multicolumn{2}{|c|}{ After 00 day } & \multicolumn{2}{|c|}{ After 30 days } & \multicolumn{2}{|c|}{ After 60 days } \\
\hline & Mean & \pm SD & Mean & \pm SD & Mean & \pm SD \\
\hline Control & $8.94^{a}$ & \pm 1.35 & $8.70^{a}$ & \pm 2.23 & $11.62^{a}$ & \pm 1.79 \\
\hline Cypermethrin & $64.77^{b}$ & \pm 2.35 & $43.42^{b^{* *}}$ & \pm 2.76 & $48.06^{b^{* *}}$ & \pm 4.58 \\
\hline Cypermethrin + Tamoxifen & $61.65^{b}$ & \pm 2.55 & $22.76^{\mathrm{c}^{\star \star \star}}$ & \pm 5.78 & $38.73^{\mathrm{c}^{\star \star}}$ & \pm 4.08 \\
\hline Tamoxifen & $22.36^{c}$ & \pm 1.89 & $14.85^{a}$ & \pm 4.06 & $19.91^{d}$ & \pm 2.38 \\
\hline ANOVA & 542.36 & & 51.48 & & 87.81 & \\
\hline $\mathbf{P}$ & $0.000^{* * *}$ & & $0.000^{* * *}$ & & $0.000^{* * *}$ & \\
\hline
\end{tabular}

Significant $*(P<0.05)$, High significant $* *(P<0.01)$, and Very high significant $* * *(P<0.001)$

ANOVA: Analysis of variance, and SD" Standard deviation

Significant differences between groups calculated by ANOVA and follow up test (LSD)

Means in the same columns assigned with the same letter show insignificant differences between these values. 


\title{
الملخص العربى
}

\section{التسمم المناعي بالبيروثيرويدات المخلقة: التاموكسفين كعامل تعديلي مضاد للتسمم بالبيرميشرين و السيبرميشرين}

\author{
ابر اهيم العليمى (1)، محمد فتحي فرج بيومي(1) ، طارق سالم (2) ، هانى ابر اهيم (1)
}

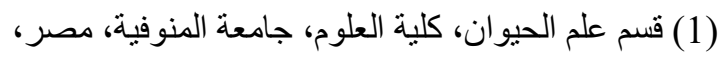

(2) معهد ابحاث الهندسه الوراثيه و التكنولوجيا الحيويه، جامعة المنوفية.

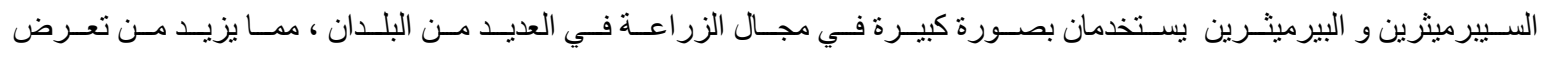

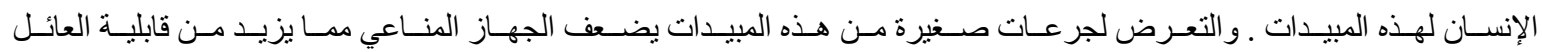

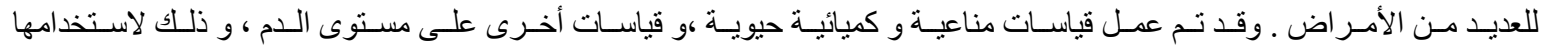

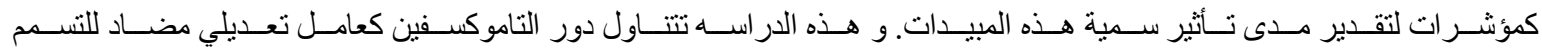

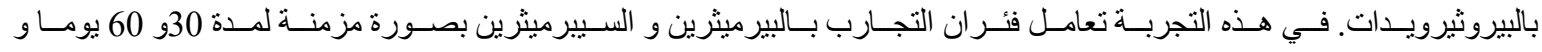

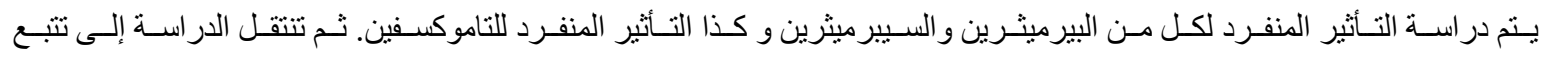

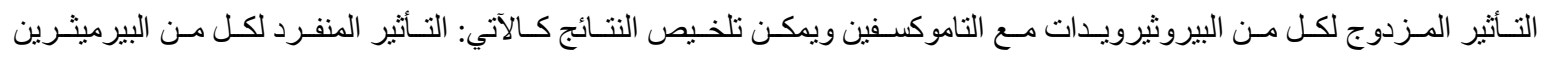

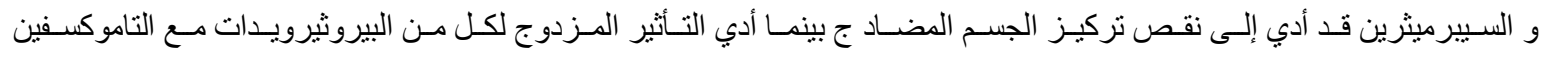

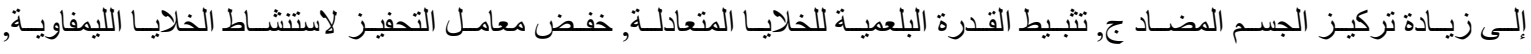

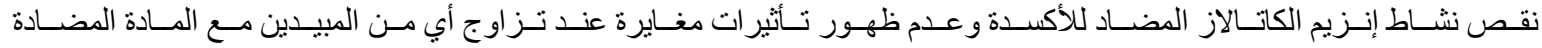

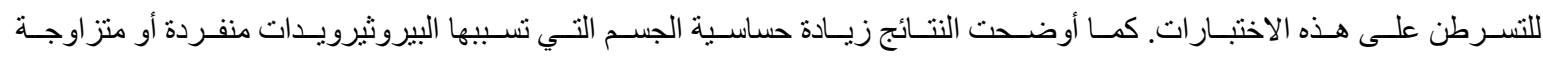

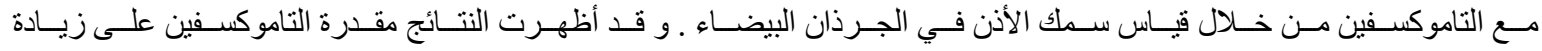

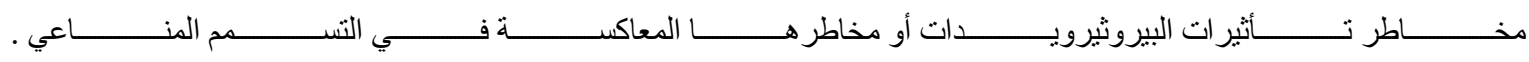

